
\title{
3 Research Suare \\ The Effect of Thyroid Hormones on Sarcopenia in a Chinese Elderly Population
}

\section{Jihai Chen}

Geriatric Hospital of Nanjing Medical University: Jiangsu Province Geriatric Hospital

Wenli Xu

the first affiliated hospital of Nanjing Medical University

Xiaoxia Zhu

the first affiliated hospital of Nanjing Medical University

\section{Xiaolan Shi}

Geriatric Hospital of Nanjing Medical University: Jiangsu Province Geriatric Hospital

\section{Jia Ren}

Geriatric Hospital of Nanjing Medical University: Jiangsu Province Geriatric Hospital

\section{Yunlu Sheng}

the first affiliated hospital of Nanjing Medical University

\section{Guoxian Ding}

the first affiliated hospital of Nanjing Medical University

\section{Xiaojun Ouyang}

Geriatric Hospital of Nanjing Medical University: Jiangsu Province Geriatric Hospital

\section{Yu Duan ( $\nabla$ duanyujsph@163.com )}

the First Affiliated Hospital of Nanjing Medical University https://orcid.org/0000-0002-0035-5915

\section{Research Article}

Keywords: Sarcopenia, THs, Elderly, Muscle strength

Posted Date: April 5th, 2021

DOl: https://doi.org/10.21203/rs.3.rs-381245/v1

License: (c) (1) This work is licensed under a Creative Commons Attribution 4.0 International License.

Read Full License 


\section{Abstract}

Purpose Sarcopenia is a common disease in the elderly. The change of hormone levels with age is proposed to be involved in the pathogenesis of sarcopenia, but the effect of thyroid hormones (THs) on sarcopenia is unclear. In this study, we aimed to analyze the effect of THs on sarcopenia.

Methods Total 309 elderly subjects (122 females and 187 males) with an average age of $85.19 \pm 7.8$ years were enrolled. Participants were divided into four groups (non-sarcopenia, sarcopenia, possible sarcopenia and serve sarcopenia) based on the consensus of the Asian Working Group for Sarcopenia in 2019. Serum levels of total triiodothyronine (TT3), free triiodothyronine (FT3), thyroxine (T4), free thyroxine (FT4), thyroid stimulating hormone (TSH), reverse triiodothyronine ( $\mathrm{rT3}$ ), and thyroxine-binding globulin (TBG) were measured. Muscle mass was measured by multifrequency bioelectrical impedance analysis (BIA). Grip was measured by spring-type dynamometer. Walking speed was represented by 6minute walk test.

Results The levels of FT3, TT3 and TSH were significantly different in four groups. Partial correlation analysis (adjusted by age and gender) indicated that FT3, TT3 and TSH had significant correlation with hand grip. In addition, TT3 was correlated with walking speed. Regression analysis showed that TT3 was a protective factor for sarcopenia and hand grip, and TSH was a protective factor for severe sarcopenia.

Conclusions $\mathrm{T} 3$ plays a protective role in sarcopenia, and this effect is achieved by affecting muscle strength but not muscle mass and gait speed. Moreover, compared with FT3, this study suggested that TT3 was more suitable to evaluate the relationship between thyroid and sarcopenia in elderly.

\section{Introduction}

Sarcopenia is a common disease in elderly, which is defined as" age-related loss of skeletal muscle (SM) mass plus loss of muscle strength and/or reduced physical performance". According to the consensus update of Asian Working Group for Sarcopenia (AWGS) in 2019, the prevalence of sarcopenia is about 7.3-12\% [1-3]. Sarcopenia is significantly correlated with cardiac disease[4] and cognitive impairment[5], and increases the risk of falls and fractures[6,7]. In addition, sarcopenia increases the risk and cost of hospitalization[8], and increases mortality $[9,10]$.

With the increase of age, muscle cross-sectional area decreases [11, 12], and the types of muscle fibers change[13]. SM fibers are classified into type 1 fibers and type 2 fibers. Type 2 fibers mainly include three types $2 a, 2 x$ and $2 b$ [11]. Type 1 muscle fibers are characterized by the expression of myosin-7 (also known as myosin heavy chain 1, MyHC区), whereas type lla fibers express myosin-2 (also known as myosin heavy chain 2a, MyHC lla), type llx fibers express myosin-1 (also known as myosin heavy chain 2x, MyHC Ilx) and type Ilb fibers express myosin-4 (also known as myosin heavy chain 2b, MyHC Ilb). In general, the sustained contraction is mediated by type 1 fibers, which are slow muscle fibers, whereas type 2 fibers perform short burst activities and are called fast muscle fibers. The mass of muscles rich in 
fast muscle fibers decreased, while that of muscles rich in slow muscle fibers decreased little or slightly $[11,14]$.

The pathogenesis of sarcopenia remains unclear. In addition to age[11, 15], neuromuscular dysfunction[13], proinflammatory cytokines, myocyte apoptosis and heredity[16], thyroid hormones (THs) are involved in the pathogenesis of sarcopenia. THs can affect the change of muscle mass and fiber types[17]. The muscle cross-sectional area is reduced in subclinical hyperthyroidism, but is improved after treatment [18],[19]. In addition, THs can promote the transition from slow muscle fiber to fast muscle fiber $[17,20]$. After the administration of triiodothyronine (T3) to the aged rats, the expression levels of MyHC Ilx and MyHC lla were upregulated in thenar muscle which was rich in slow muscle fibers [21]. The relationship between THs and sarcopenia has been confirmed in animal studies. However, in clinical studies, the conclusion on the relationship between THs and sarcopenia is inconsistent[22-24]. The purpose of this study is to analyze the relationship between THs and sarcopenia based on clinical data, and examine the effect of THs on sarcopenia.

\section{Methods}

\section{Subjects}

Total 309 elderly subjects (aged $\geq 60$ years) were included in this study, and all of them were from the Geriatric Hospital of Nanjing Medical University. Most of them were over 80 years old $(n=233,75.46 \%)$. The mean age was $85.19 \pm 7.84$ years. The proportion of female was $39.48 \%$ (female: $n=122$, male: $n=187)$.

All the subjects had complete records of the disease history and medication history. The patients who took glucocorticoids, androgens, thyroxine and other drugs that may affect thyroid function and muscle were excluded. The subjects with thyroid dysfunction, acute infection, acute liver dysfunction, acute kidney dysfunction, stroke sequelae, Parkinson's disease and other diseases that may affect muscle function were also excluded. The study was approved by the Geriatric Hospital of Nanjing Medical University Institutional Review Board.

\section{Thyroid function}

Blood samples were collected from all subjects at least 8 hours after fasting, and total triiodothyronine (TT3), free triiodothyronine (FT3), thyroxine (T4), free thyroxine (FT4), thyroid stimulating hormone (TSH), reverse triiodothyronine ( $r T 3$ ), and thyroxine-binding globulin (TBG) were measured (Roche electrochemiluminescence instrument E170).

\section{Assessment of grip}


All subjects stood with full elbow extension, and used the hand dynamometer (CAMRY, Beijing, China) to measure the grip of the dominant hand. Three attempts with a 1-min interval and the maximum value were recorded. According to the 2019 consensus of AWGS, the low muscle strength diagnostic cutoffs of grip are $<28.0 \mathrm{~kg}$ for men and $<18.0 \mathrm{~kg}$ for women.

\section{Assessment of muscle mass}

The bioelectrical impedance analysis (BIA) (InBody S10) was used to measure appendicular skeletal muscle mass (ASM). The appendicular skeletal muscle mass index (SMI) was calculated as: SMI $(\mathrm{kg} / \mathrm{m} 2)=\operatorname{ASM}(\mathrm{kg}) /$ height $^{2}\left(\mathrm{~m}^{2}\right)$.

Height and weight were measured by standard methods with light clothing without shoes. Body mass index (BMI) was calculated as: BMI $\left(\mathrm{kg} / \mathrm{m}^{2}\right)=$ Weight $(\mathrm{kg}) / \mathrm{height}^{2}\left(\mathrm{~m}^{2}\right)$. According to AWGS 2019 consensus, low SMI is $<7.0 \mathrm{~kg} / \mathrm{m}^{2}$ in men and $<5.7 \mathrm{~kg} / \mathrm{m}^{2}$ in women.

\section{Assessment of gait speed}

The 6-metre (6 m) walk test was used to measure gait speed (GS). According to AWGS 2019 consensus, the cutoff for slow GS is $<1 \mathrm{~m} / \mathrm{s}$.

\section{Diagnosis of sarcopenia}

According to the consensus of AWGS 2019, the definition of sarcopenia includes low SMI, combined with low grip or slow GS. Severe sarcopenia is defined as low SMI, combined with low grip and slow GS. Possible sarcopenia is defined as normal SMI but low grip, with or without slow GS.

\section{Statistical analysis}

Descriptive data were presented as means $(M) \pm$ standard deviation (SD). Pearson's Partial correlation analysis was used in correlation analysis. Multiple linear regression models were applied for degrees of sarcopenia and sarcopenia elements, using age, gender and thyroid function. One-way ANOVA analysis was performed to compare baseline data, thyroid function and the sarcopenia elements among the normal, possible sarcopenia, sarcopenia and serve sarcopenia groups. All statistical analyses were performed using SPSS version 20.0 (IBM Corp, Armonk, NY, USA), and $p<0.05$ was considered statistically significant.

\section{Results}




\section{General characteristics, SMI, grip, GS, and THs levels of participants}

According to the consensus of AWGS 2019, all patients were divided into non-sarcopenia group, possible sarcopenia group, sarcopenia group and severe sarcopenia group. Among all 309 subjects, 103 were diagnosed with sarcopenia (sarcopenia and severe sarcopenia) and the prevalence rate was $33.33 \%$, while 102 were diagnosed with possible sarcopenia and the prevalence rate was $33.01 \%$. The baseline data of the four groups are shown in Table 1.

The age $(F=16.53, p<0.01)$, the proportion of female $(F=4.69, p<0.01)$, grip $(F=53.74, p<0.01)$, SMI ( $F$ $=67.19, p<0.01)$ and $\mathrm{GS}(\mathrm{F}=21.80, p<0.01)$ were significantly different among four groups. Moreover, the levels of FT3 $(\mathrm{F}=5.73, p<0.01)$, TT3 $(\mathrm{F}=6.42, p<0.01)$ and TSH $(\mathrm{F}=5.05, p<0.01)$ had significant differences while the levels of FT4, TT4, rT3 and TBG had no significant differences among the four groups. 
Table 1

General characteristics, SMI, grip, GS, and THs levels of participants

\begin{tabular}{|c|c|c|c|c|c|c|}
\hline & \multirow[t]{2}{*}{ Total } & \multirow{2}{*}{$\begin{array}{l}\text { Non- } \\
\text { sarcopenia }\end{array}$} & \multicolumn{3}{|c|}{ Sarcopenia } & \multirow{2}{*}{$\begin{array}{l}p \\
\text { value }\end{array}$} \\
\hline & & & $\begin{array}{l}\text { Possible } \\
\text { sarcopenia }\end{array}$ & Sarcopenia & $\begin{array}{l}\text { Severe } \\
\text { sarcopenia }\end{array}$ & \\
\hline $\mathrm{n}$ & 309 & 104 & 102 & 44 & 59 & \\
\hline Female (\%) & $\begin{array}{l}122 \\
(39.48 \%)\end{array}$ & $\begin{array}{l}51 \\
(49.04 \%)\end{array}$ & $45(44.12 \%)$ & $11(25.00 \%)$ & $15(25.42 \%)$ & $0.003^{*}$ \\
\hline Age(y) & $\begin{array}{l}85.19 \pm \\
7.84\end{array}$ & $\begin{array}{l}81.61 \pm \\
8.72\end{array}$ & $87.50 \pm 5.97$ & $\begin{array}{l}83.74 \pm \\
8.36\end{array}$ & $88.58 \pm 5.65$ & $0.000 *$ \\
\hline $\mathrm{BMI}\left(\mathrm{kg} / \mathrm{m}^{2}\right)$ & $\begin{array}{l}24.35 \pm \\
3.68\end{array}$ & $\begin{array}{l}24.24 \pm \\
3.18\end{array}$ & $24.55 \pm 4.36$ & $\begin{array}{l}24.00 \pm \\
3.32\end{array}$ & $24.46 \pm 3.68$ & 0.850 \\
\hline $\operatorname{ALT}(\mathrm{U} / \mathrm{L})$ & $\begin{array}{l}18.19 \pm \\
16.20\end{array}$ & $\begin{array}{l}17.59 \pm \\
15.86\end{array}$ & $20.37 \pm 21.77$ & $\begin{array}{l}16.36 \pm \\
8.03\end{array}$ & $16.98 \pm 8.06$ & 0.443 \\
\hline $\operatorname{ALB}(\mathrm{g} / \mathrm{L})$ & $\begin{array}{l}38.37 \pm \\
3.93\end{array}$ & $\begin{array}{l}38.14 \pm \\
3.71\end{array}$ & $38.43 \pm 4.12$ & $\begin{array}{l}38.51 \pm \\
3.83\end{array}$ & $38.57 \pm 4.14$ & 0.912 \\
\hline $\operatorname{SCR}(\mu \mathrm{mol} / \mathrm{L})$ & $\begin{array}{l}82.18 \pm \\
27.05\end{array}$ & $\begin{array}{l}82.17 \pm \\
26.52\end{array}$ & $82.46 \pm 19.40$ & $\begin{array}{l}78.28 \pm \\
30.56\end{array}$ & $\begin{array}{l}84.84 \pm \\
35.76\end{array}$ & 0.711 \\
\hline $\mathrm{GLU}(\mathrm{mmol} / \mathrm{L})$ & $\begin{array}{l}5.84 \pm \\
1.65\end{array}$ & $5.83 \pm 1.75$ & $5.78 \pm 1.62$ & $5.77 \pm 1.25$ & $6.03 \pm 1.82$ & 0.578 \\
\hline \multicolumn{7}{|c|}{ Sarcopenia elements } \\
\hline Grip(kg) & $\begin{array}{l}23.58 \pm \\
7.40\end{array}$ & $\begin{array}{l}27.95 \pm \\
7.49\end{array}$ & $18.99 \pm 5.15$ & $\begin{array}{l}28.76 \pm \\
4.69\end{array}$ & $19.95 \pm 4.88$ & $0.000 *$ \\
\hline $\mathrm{SMI}\left(\mathrm{kg} / \mathrm{m}^{2}\right)$ & $\begin{array}{l}6.93 \pm \\
1.14\end{array}$ & $7.34 \pm 1.04$ & $7.54 \pm 0.87$ & $5.96 \pm 0.65$ & $5.90 \pm 0.78$ & $0.000 *$ \\
\hline $\mathrm{GS}(\mathrm{m} / \mathrm{s})$ & $\begin{array}{l}0.68 \pm \\
0.23\end{array}$ & $0.80 \pm 0.21$ & $0.60 \pm 0.21$ & $0.71 \pm 0.18$ & $0.58 \pm 0.22$ & $0.000 *$ \\
\hline \multicolumn{7}{|c|}{ Thyroid function } \\
\hline FT3(pmol/L) & $\begin{array}{l}4.02 \pm \\
0.69\end{array}$ & $4.19 \pm 0.62$ & $3.91 \pm 0.69$ & $4.14 \pm 0.72$ & $3.79 \pm 0.70$ & $0.001 *$ \\
\hline $\mathrm{FT} 4(\mathrm{pmol} / \mathrm{L})$ & $\begin{array}{l}13.73 \pm \\
1.98\end{array}$ & $\begin{array}{l}13.61 \pm \\
1.99\end{array}$ & $13.72 \pm 2.06$ & $\begin{array}{l}14.00 \pm \\
1.97\end{array}$ & $13.73 \pm 1.98$ & 0.752 \\
\hline TT3(ng/ml) & $\begin{array}{l}0.82 \pm \\
0.19\end{array}$ & $0.87 \pm 0.19$ & $0.77 \pm 0.16$ & $0.84 \pm 0.24$ & $0.77 \pm 0.17$ & $0.000 *$ \\
\hline TT4(nmol/L) & $\begin{array}{l}90.39 \pm \\
21.37\end{array}$ & $\begin{array}{l}91.68 \pm \\
24.79\end{array}$ & $89.55 \pm 19.74$ & $\begin{array}{l}92.98 \pm \\
23.83\end{array}$ & $\begin{array}{l}87.60 \pm \\
14.65\end{array}$ & 0.541 \\
\hline
\end{tabular}

${ }^{*} p$ value $<0.05$, comparison among the four groups 


\begin{tabular}{|c|c|c|c|c|c|c|}
\hline & \multirow[t]{2}{*}{ Total } & \multirow{2}{*}{$\begin{array}{l}\text { Non- } \\
\text { sarcopenia }\end{array}$} & \multicolumn{3}{|c|}{ Sarcopenia } & \multirow{2}{*}{$\begin{array}{l}p \\
\text { value }\end{array}$} \\
\hline & & & $\begin{array}{l}\text { Possible } \\
\text { sarcopenia }\end{array}$ & Sarcopenia & $\begin{array}{l}\text { Severe } \\
\text { sarcopenia }\end{array}$ & \\
\hline TSH(ulU/ml) & $\begin{array}{l}2.41 \pm \\
1.66\end{array}$ & $2.51 \pm 1.36$ & $2.40 \pm 1.80$ & $3.03 \pm 2.37$ & $1.80 \pm 0.90$ & $0.002^{\star}$ \\
\hline rT3(nmol/L) & $\begin{array}{l}1.89 \pm \\
0.20\end{array}$ & $1.91 \pm 0.25$ & $1.89 \pm 0.21$ & $1.87 \pm 0.22$ & $1.92 \pm 0.15$ & 0.879 \\
\hline TBG (ng/ml) & $\begin{array}{l}7.18 \pm \\
0.80\end{array}$ & $6.95 \pm 0.70$ & $7.32 \pm 0.75$ & $7.19 \pm 1.03$ & $7.19 \pm 0.63$ & 0.535 \\
\hline
\end{tabular}

\section{Correlation between THs and sarcopenia elements}

After adjusting for age and gender, we analyzed the correlation between partial thyroid function (FT3, TT3 and TSH) and sarcopenia elements (SMI, Grip and GS). The results indicated that grip was significantly correlated with FT3 $(r=0.151, p<0.01)$, TT3 (OR $=0.175, p<0.01)$ and TSH $(r=0.149, p<0.01)$, while GS was significantly correlated with TT3 $(r=0.183, p<0.01)$.

A FT3 and SMI. B FT3 and grip. C FT3 and GS. D TT3 and SMI. ETT3 and grip. F TT3 and GS. G TSH and SMI. H TSH and grip. I TSH and GS.

${ }^{*} p$ value $<0.05$

\section{Effect of THs on sarcopenia}

The results of multiple regression analysis indicated that the risk of sarcopenia $(\mathrm{OR}=1.080, p<0.01)$, low grip $(\mathrm{OR}=1.056, p<0.01)$ and low $\mathrm{GS}(\mathrm{OR}=1.132, p<0.01)$ increases with age. Moreover, TT3, but not FT3, FT4, TT4 and TSH, was a protective factor for sarcopenia (OR $=0.115, p<0.05)$ and low grip (OR = $0.165, p<0.05)$. In addition, compared with male, female had a lower risk of low SMI $(\mathrm{OR}=0.392, p<$ $0.01)$. 
Table 2

the effect of THs on sarcopenia

\begin{tabular}{|c|c|c|c|c|c|c|c|c|}
\hline & \multicolumn{2}{|c|}{ sarcopenia } & \multicolumn{2}{|l|}{ Low SMI } & \multicolumn{2}{|l|}{ Low Grip } & \multicolumn{2}{|l|}{ Slow GS } \\
\hline & $\begin{array}{l}\text { OR } \\
(95 \% \mathrm{Cl})\end{array}$ & $p$ & $\begin{array}{l}\text { OR } \\
(95 \% \mathrm{Cl})\end{array}$ & $p$ & $\begin{array}{l}\text { OR } \\
(95 \% \mathrm{Cl})\end{array}$ & $p$ & $\begin{array}{l}\text { OR } \\
(95 \% \mathrm{Cl})\end{array}$ & $p$ \\
\hline \multirow[t]{2}{*}{ Age } & 1.080 & $0.000^{*}$ & 0.993 & 0.678 & 1.056 & $0.001^{*}$ & 1.132 & $0.000^{*}$ \\
\hline & $\begin{array}{l}(1.053- \\
1.148)\end{array}$ & & $\begin{array}{l}(0.961- \\
1.026)\end{array}$ & & $\begin{array}{l}(1.022- \\
1.091)\end{array}$ & & $\begin{array}{l}(1.074- \\
1.194)\end{array}$ & \\
\hline \multirow[t]{2}{*}{ Gender(F) } & 0.625 & 0.077 & 0.392 & $0.001^{*}$ & 1.277 & 0.321 & 0.925 & 0.862 \\
\hline & $\begin{array}{l}(0.371- \\
1.052)\end{array}$ & & $\begin{array}{l}(0.230- \\
0.669)\end{array}$ & & $\begin{array}{l}(0.788- \\
2.071)\end{array}$ & & $\begin{array}{l}(0.383- \\
2.235)\end{array}$ & \\
\hline \multirow[t]{2}{*}{ FT3 } & 0.875 & 0.600 & 0.979 & 0.929 & 0.706 & 0.647 & 0.902 & 0.803 \\
\hline & $\begin{array}{l}(0.530- \\
1.443)\end{array}$ & & $\begin{array}{l}(0.612- \\
1.566)\end{array}$ & & $\begin{array}{l}(0.112- \\
1.752)\end{array}$ & & $\begin{array}{l}(0.403- \\
2.023)\end{array}$ & \\
\hline \multirow[t]{2}{*}{ FT4 } & 1.044 & 0.593 & 1.021 & 0.780 & 0.960 & 0.577 & 0.936 & 0.613 \\
\hline & $\begin{array}{l}(0.891- \\
1.224)\end{array}$ & & $\begin{array}{l}(0.881- \\
1.183)\end{array}$ & & $\begin{array}{l}(0.833- \\
1.107)\end{array}$ & & $\begin{array}{l}(0.723- \\
1.211)\end{array}$ & \\
\hline \multirow[t]{2}{*}{ TT3 } & 0.115 & $0.031^{*}$ & 0.925 & 0.931 & 0.165 & $0.046^{*}$ & 1.015 & 0.116 \\
\hline & $\begin{array}{l}(0.016- \\
0.821)\end{array}$ & & $\begin{array}{l}(0.158- \\
5.423)\end{array}$ & & $\begin{array}{l}(0.028- \\
0.972)\end{array}$ & & $\begin{array}{l}(0.004- \\
1.855)\end{array}$ & \\
\hline \multirow[t]{2}{*}{ TT4 } & 1.010 & 0.199 & 1.005 & 0.530 & 1.007 & 0.327 & 1.015 & 0.219 \\
\hline & $\begin{array}{l}(0.995- \\
1.026)\end{array}$ & & $\begin{array}{l}(0.990- \\
1.020)\end{array}$ & & $\begin{array}{l}(0.993- \\
1.022)\end{array}$ & & $\begin{array}{l}(0.991- \\
1.041)\end{array}$ & \\
\hline \multirow[t]{2}{*}{ TSH } & 1.030 & 0.720 & 1.011 & 0.885 & 1.084 & 0.280 & 0.921 & 0.517 \\
\hline & $\begin{array}{l}(0.876- \\
1.211)\end{array}$ & & $\begin{array}{l}(0.870- \\
1.176)\end{array}$ & & $\begin{array}{l}(0.936- \\
1.255)\end{array}$ & & $\begin{array}{l}(0.719- \\
1.181)\end{array}$ & \\
\hline
\end{tabular}

\section{Discussion}

Sarcopenia is one of the common diseases in the elderly. The prevalence of sarcopenia increases with age. In this study the prevalence of sarcopenia was $33.33 \%$ in the selected elderly Chinese population, similar to the results of previous study [25].

Previous studies indicated that THs participated in skeletal muscle contractile function, metabolism, myogenesis and regeneration $[17,20,26]$. The rats with hypothyroidism presented a delay in the switch to adult myosin in SM rich fast fibers, but not in SM rich slow fibers $[27,28]$. The muscle cross-sectional 
area had mild decrease in subclinical hypothyroidism rats, and THs may affect the type of muscle fibers. However, some clinical studies suggested that thyroid function had no significant effect on sarcopenia[18]. Therefore, we performed this study to clarify the relationship between thyroid and sarcopenia.

Compared with non-sarcopenia groups, the levels of FT3, TT3, TSH in possible sarcopenia group and sarcopenia group were different, suggesting that THs might have effect on sarcopenia. In addition, partial correlation analysis showed the correlation between THs (FT3, TT3 and TSH) and elements of sarcopenia (grip and gait speed). The multiple regression analysis further confirmed that TT3 was independently associated with sarcopenia and grip, but not with SMI and GS. These results suggested that TT3 had protective effect on sarcopenia by affecting the muscle strength.

Actually, compared with TT3, FT3 plays a major physiological role in muscle [29, 30], but it is also vulnerable to fluctuations, especially in the elderly[29, 31]. In our study, most of subjects were over 80 years old $(n=233,75.46 \%)$. We did not find a significant correlation between FT3 and sarcopenia, which may be due to the fluctuation of serum FT3 level in elderly patients. Although patients with acute cardiovascular and cerebrovascular diseases, acute infection and other diseases were excluded in this study, the elderly population is prone to the fluctuations in FT3 level due to several factors such as age and multiple diseases. Therefore, compared with FT3, the level of TT3 may be a better indicator in the elderly population.

This study has some limitations such as small sample size, and our results need to be further evaluated by expanding the sample size. In addition, we found that TT3 was associated with sarcopenia and grip strength, but the mechanism is not clear. Further studies are needed to confirm the role of TT3 in the pathogenesis of sarcopenia.

In conclusion, this study suggested that TT3 plays a protective role in sarcopenia, and this effect is achieved by affecting muscle strength but not muscle mass and gait speed. Moreover, compared with FT3, this study suggested that TT3 was more suitable to evaluate the relationship between thyroid and sarcopenia in elderly. This study revealed that higher T3 concentration within normal range is necessary and beneficial for sarcopenia in elderly subjects.

\section{Declarations}

\section{Acknowledgements:}

The authors appreciate all of individuals for their assistance in this study.

\section{Funding}


This work was supported by National Natural Science Foundation of China (No. 81670724『82071582) and Jiangsu Health Commission Foundation of China (No. BJ19029, H2019038).

\section{Author contributions}

JHC, XJOY and YD contributed to the study conception and design. WLX, XXZ, XLS, JR, GXZ, and YLS performed data collection and analysis. The first draft of the manuscript was written by JHC and all authors commented on previous versions of the manuscript. All authors read and approved the final manuscript.

Compliance with ethical standards

\section{Conflict of interest}

There are no conflicts of interest to declare.

\section{Ethics approval}

The study was approved by the Geriatric Hospital of Nanjing Medical University Institutional Review Board, and the study was performed in accordance with the ethical standards as laid down in the 1964 Declaration of Helsinki and its later amendments or comparable ethical standards.

\section{Informed consent}

All participants provided informed consent.

\section{References}

1. Yoshimura, N., Muraki, S., Oka, H., lidaka, T., Kodama, R., Kawaguchi, H., Nakamura, K., Tanaka, S. \& Akune, T. Is osteoporosis a predictor for future sarcopenia or vice versa? Four-year observations between the second and third ROAD study surveys. Osteoporos Int 28, 189-199 (2017).https://doi.org/10.1007/s00198-016-3823-0

2. Yu, R., Leung, J. \& Woo, J. Incremental predictive value of sarcopenia for incident fracture in an elderly Chinese cohort: results from the Osteoporotic Fractures in Men (MrOs) Study. J Am Med Dir Assoc 15, 551-558 (2014).https://doi.org/10.1016/j.jamda.2014.02.005

3. Woo, J., Leung, J. \& Morley, J.E. Defining sarcopenia in terms of incident adverse outcomes. J Am Med Dir Assoc 16, 247-252 (2015).https://doi.org/10.1016/j.jamda.2014.11.013

4. Tamura, Y., Ishikawa, J., Fujiwara, Y., Tanaka, M., Kanazawa, N., Chiba, Y., lizuka, A., Kaito, S., Tanaka, J., Sugie, M., Nishimura, T., Kanemaru, A., Shimoji, K., Hirano, H., Furuta, K., Kitamura, A., Seino, S., 
Shinkai, S., Harada, K., Kyo, S., Ito, H. \& Araki, A. Prevalence of frailty, cognitive impairment, and sarcopenia in outpatients with cardiometabolic disease in a frailty clinic. BMC Geriatr 18, 264 (2018).https://doi.org/10.1186/s12877-018-0955-4

5. Chang, K.V., Hsu, T.H., Wu, W.T., Huang, K.C. \& Han, D.S. Association Between Sarcopenia and Cognitive Impairment: A Systematic Review and Meta-Analysis. J Am Med Dir Assoc 17, 1164 e11671164 e1115 (2016).https://doi.org/10.1016/j.jamda.2016.09.013

6. Bischoff-Ferrari, H.A., Orav, J.E., Kanis, J.A., Rizzoli, R., Schlogl, M., Staehelin, H.B., Willett, W.C. \& Dawson-Hughes, B. Comparative performance of current definitions of sarcopenia against the prospective incidence of falls among community-dwelling seniors age 65 and older. Osteoporos Int 26, 2793-2802 (2015).https://doi.org/10.1007/s00198-015-3194-y

7. Schaap, L.A., van Schoor, N.M., Lips, P. \& Visser, M. Associations of Sarcopenia Definitions, and Their Components, With the Incidence of Recurrent Falling and Fractures: The Longitudinal Aging Study Amsterdam. J Gerontol A Biol Sci Med Sci 73, 1199-1204 (2018).https://doi.org/10.1093/gerona/glx245

8. Cawthon, P.M., Lui, L.Y., Taylor, B.C., McCulloch, C.E., Cauley, J.A., Lapidus, J., Orwoll, E. \& Ensrud, K.E. Clinical Definitions of Sarcopenia and Risk of Hospitalization in Community-Dwelling Older Men: The Osteoporotic Fractures in Men Study. J Gerontol A Biol Sci Med Sci 72, 1383-1389 (2017).https://doi.org/10.1093/gerona/glw327

9. De Buyser, S.L., Petrovic, M., Taes, Y.E., Toye, K.R., Kaufman, J.M., Lapauw, B. \& Goemaere, S. Validation of the FNIH sarcopenia criteria and SOF frailty index as predictors of long-term mortality in ambulatory older men. Age Ageing 45, 602-608 (2016).https://doi.org/10.1093/ageing/afw071

10. Yu, R., Leung, J. \& Woo, J. Sarcopenia combined with FRAX probabilities improves fracture risk prediction in older Chinese men. J Am Med Dir Assoc 15, 918-923 (2014).https://doi.org/10.1016/j.jamda.2014.07.011

11. Schiaffino, S. \& Reggiani, C. Fiber types in mammalian skeletal muscles. Physiol Rev 91, 1447-1531 (2011).https://doi.org/10.1152/physrev.00031.2010

12. Doherty, T.J. Invited review: Aging and sarcopenia. J Appl Physiol (1985) 95, 1717-1727 (2003).https://doi.org/10.1152/japplphysiol.00347.2003

13. Goljanek-Whysall, K., Iwanejko, L.A., Vasilaki, A., Pekovic-Vaughan, V. \& McDonagh, B. Ageing in relation to skeletal muscle dysfunction: redox homoeostasis to regulation of gene expression. Mamm Genome 27, 341-357 (2016).https://doi.org/10.1007/s00335-016-9643-x

14. Nilwik, R., Snijders, T., Leenders, M., Groen, B.B., van Kranenburg, J., Verdijk, L.B. \& van Loon, L.J. The decline in skeletal muscle mass with aging is mainly attributed to a reduction in type II muscle fiber size. Exp Gerontol 48, 492-498 (2013).https://doi.org/10.1016/j.exger.2013.02.012

15. Larsson, L., Edstrom, L., Lindegren, B., Gorza, L. \& Schiaffıno, S. MHC composition and enzymehistochemical and physiological properties of a novel fast-twitch motor unit type. Am J Physiol 261, C93-101 (1991).https://doi.org/10.1152/ajpcell.1991.261.1.C93 
16. Cruz-Jentoft, A.J. \& Sayer, A.A. Sarcopenia. Lancet 393, 2636-2646 (2019).https://doi.org/10.1016/S0140-6736(19)31138-9

17. Simonides, W.S. \& van Hardeveld, C. Thyroid hormone as a determinant of metabolic and contractile phenotype of skeletal muscle. Thyroid 18, 205-216 (2008).https://doi.org/10.1089/thy.2007.0256

18. Moon, M.K., Lee, Y.J., Choi, S.H., Lim, S., Yang, E.J., Lim, J.Y., Paik, N.J., Kim, K.W., Park, K.S., Jang, H.C., Cho, B.Y. \& Park, Y.J. Subclinical hypothyroidism has little influences on muscle mass or strength in elderly people. J Korean Med Sci $25,1176-1181$ (2010).https://doi.org/10.3346/jkms.2010.25.8.1176

19. Brennan, M.D., Powell, C., Kaufman, K.R., Sun, P.C., Bahn, R.S. \& Nair, K.S. The impact of overt and subclinical hyperthyroidism on skeletal muscle. Thyroid $16,375-380$ (2006).https://doi.org/10.1089/thy.2006.16.375

20. Salvatore, D., Simonides, W.S., Dentice, M., Zavacki, A.M. \& Larsen, P.R. Thyroid hormones and skeletal muscle--new insights and potential implications. Nat Rev Endocrinol 10, 206-214 (2014).https://doi.org/10.1038/nrendo.2013.238

21. Larsson, L., Muller, U., Li, X. \& Schiaffino, S. Thyroid hormone regulation of myosin heavy chain isoform composition in young and old rats, with special reference to IIX myosin. Acta Physiol Scand 153, 109-116 (1995).https://doi.org/10.1111/j.1748-1716.1995.tb09841.x

22. Chen, L. \& Hu, Y. The correlation between serum thyroid hormone levels and hand grip among elderly male Chinese inpatients. Aging Male, 1-6 (2019).https://doi.org/10.1080/13685538.2019.1634044

23. Sheng, Y., Ma, D., Zhou, Q., Wang, L., Sun, M., Wang, S., Qi, H., Liu, J., Ding, G. \& Duan, Y. Association of thyroid function with sarcopenia in elderly Chinese euthyroid subjects. Aging Clin Exp Res 31, 1113-1120 (2019).https://doi.org/10.1007/s40520-018-1057-z

24. Szlejf, C., Suemoto, C.K., Janovsky, C., Barreto, S.M., Diniz, M., Lotufo, P.A. \& Bensenor, I.M. Thyroid Function and Sarcopenia: Results from the ELSA-Brasil Study. J Am Geriatr Soc 68, 1545-1553 (2020).https://doi.org/10.1111/jgs.16416

25. von Haehling, S., Morley, J.E. \& Anker, S.D. An overview of sarcopenia: facts and numbers on prevalence and clinical impact. J Cachexia Sarcopenia Muscle 1, 129-133 (2010).https://doi.org/10.1007/s13539-010-0014-2

26. Dentice, M., Marsili, A., Ambrosio, R., Guardiola, O., Sibilio, A., Paik, J.H., Minchiotti, G., DePinho, R.A., Fenzi, G., Larsen, P.R. \& Salvatore, D. The FoxO3/type 2 deiodinase pathway is required for normal mouse myogenesis and muscle regeneration. J Clin Invest 120, 4021-4030 (2010).https://doi.org/10.1172/JCl43670

27. Gambke, B., Lyons, G.E., Haselgrove, J., Kelly, A.M. \& Rubinstein, N.A. Thyroidal and neural control of myosin transitions during development of rat fast and slow muscles. FEBS Lett 156, 335-339 (1983).https://doi.org/10.1016/0014-5793(83)80524-9

28. di Maso, N.A., Caiozzo, V.J. \& Baldwin, K.M. Single-fiber myosin heavy chain polymorphism during postnatal development: modulation by hypothyroidism. Am J Physiol Regul Integr Comp Physiol 278, R1099-1106 (2000).https://doi.org/10.1152/ajpregu.2000.278.4.R1099 
29. Selvaraj, N., Bobby, Z. \& Sridhar, M.G. Is euthyroid sick syndrome a defensive mechanism against oxidative stress? Med Hypotheses 71, 404-405 (2008).https://doi.org/10.1016/j.mehy.2007.11.019

30. Ortiga-Carvalho, T.M., Chiamolera, M.I., Pazos-Moura, C.C. \& Wondisford, F.E. Hypothalamus-PituitaryThyroid Axis. Compr Physiol 6, 1387-1428 (2016).https://doi.org/10.1002/cphy.c150027

31. Afandi, B., Schussler, G.C., Arafeh, A.H., Boutros, A., Yap, M.G. \& Finkelstein, A. Selective consumption of thyroxine-binding globulin during cardiac bypass surgery. Metabolism 49, 270-274 (2000).https://doi.org/10.1016/s0026-0495(00)91611-1

\section{Figures}
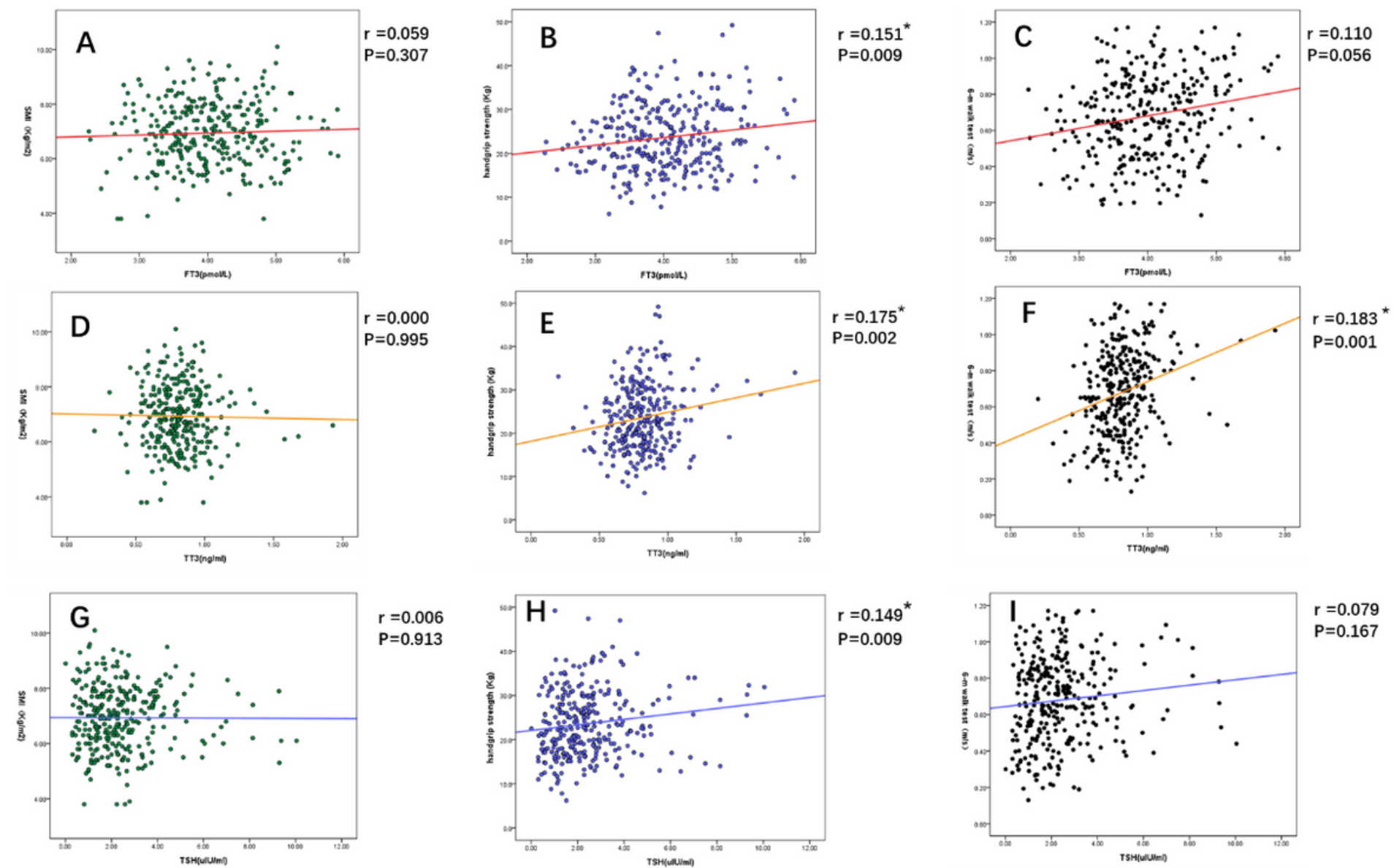

Figure 1

The correlation between sarcopenia elements and THs levels after adjusting for the gender and age. 